\title{
Records of chromatic disorder in Molossus molossus and Sturnira bakeri (Chiroptera) from western Ecuador
}

\author{
Registros de desorden cromático en Molossus molossus y Sturnira bakeri (Chiroptera) en \\ el occidente de Ecuador
}

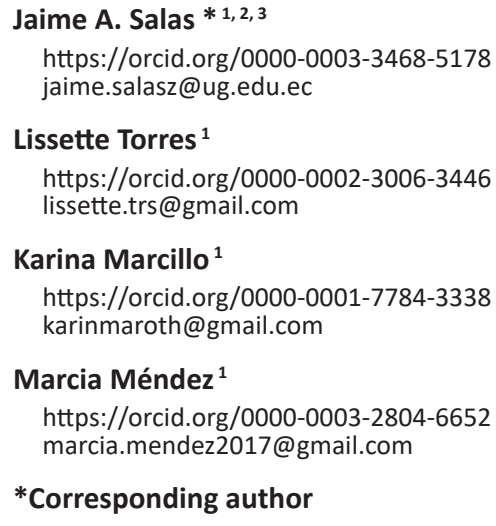

\section{*Corresponding author}

1 Universidad de Guayaquil-Facultad de Ciencias Naturales, Carrera de Biología, Ecuador.

2 Universidad Espíritu Santo, Samborondón. Ecuador. 3 Fundación Desarrollo y Biodiversidad-FUNDEBIO.

\section{Citación}

Salas JA, Torres L, Marcillo K, Méndez M. 2021. Records of chromatic disorder in Molossus molossus and Sturnira bakeri (Chiroptera) from western Ecuador. Revista peruana de biología 28(2): e18469 (Mayo 2021). doi: http://dx.doi.org/10.15381/rpb.v28i2.18469

$\begin{array}{ll}\text { Presentado: } & 17 / 08 / 2020 \\ \text { Aceptado: } & 14 / 10 / 2020 \\ \text { Publicado online: } & 25 / 05 / 2021\end{array}$

Publicado online: 25/05/2021

Editor:

Victor Pacheco

\section{Resumen}

Reportamos casos de leucismo en las especies de murciélagos Molossus molossus y Sturnira bakeri capturados en tres localidades de tierras bajas del occidente de Ecuador, los cuales incluyen tres hembras grávidas, cinco juveniles, cuatro subadultas, y seis adultos. Los ejemplares de $M$. molossus presentaron manchas blancas en distintas partes blandas del cuerpo (orejas, trago, propatagio y uropatagio) y en el pelo (garganta y abdomen), mientras que el ejemplar de Sturnira bakeri presentó un parche blanco-amarillento en la región dorsal, a nivel del omoplato, muy contrastante en murciélagos de hombros amarillos. En América del Sur, se tiene poco conocimiento sobre los trastornos cromáticos en los murciélagos, por lo que es necesario informar estos casos e investigar los factores que los provocan.

\section{Abstract}

Herein we report cases of leucism in Molossus molossus and Sturnira bakeri from three locations of lowlands of western Ecuador, which include three gravid females, five juvenile, four subadult, and six adults. The M. molossus specimens showed white spots on several parts in the soft part of body (ears, tragus, propatagium, uropatagium), and fur (throat, abdomen), while individual of $S$. bakeri presented a whitish-yellowish patch on its dorsal region, very contrast in yellow-shoulder bats. Although South America has a significant information gap about chromatic disorders in bats, been necessary to continue reporting cases of chromatic disorders to try to determine their causes.

Palabras claves:

Molossus molossus; Sturnira bakeri; anomalías pigmentarias; tierras bajas de la costa ecuatoriana.

\section{Keywords:}

Molossus molossus; Sturnira bakeri; chromatic disorders; Ecuadorian coastal lowland.

\section{Introduction}

Diverse faunal groups can show atypical or abnormal coloration on the body; these abnormalities have been classified according to their phenotypic characteristics as albinism, leucism and melanism. In albinism, the pelage and skin are whitish, and the coloration of the eyes is red; in leucism, white spots appear on various regions of the body, but the coloration of the eyes is normal; and in melanism, hyperpigmentation or darkening of hair tones is present (Uieda 2000, Sánchez-Hernández et al. 2010, Tello et al. 2014, Lucati \& LópezBaucells 2016, Zortéa \& Silva 2018). These pigmentary disorders are attributed to the expression of mutant alleles (Bensch et al. 2000, Moller \& Mousseau 2001) or the enzyme tyrosinase absence, which produces melanin in vertebrates (Lucati \& López-Baucells 2016, Za- 
lapa et al. 2016). The colour abnormalities have also been attributed to environmental or biological factors (Holyoak 1978, Lucati \& López-Bauchells 2016, Moller \& Mousseau 2001) such as geographic isolation that limits connectivity between populations, inducing inbreeding (Bensch et al. 2000, Chętnicki et al. 2007).

These chromatic disorders have been reported in individuals of the Phyllostomidae, Mormoopidae, Molossidae, and Vespertilionidae families from North and South America (Caire \& Thies 1988, Geiger \& Pacheco 2006, Hernández-Mijangos 2009, Idoeta et al. 2011, García-Morales et al. 2012, 2013, Ruelas et al. 2016, Zortéa \& Silva 2018, Hernández-Aguilar \& Santos-Moreno 2018). For example, in South America, cases of these conditions have been reported in molossids in the genera Molossus, Eumops, Nyctinomops, and Tadarida in Peru (Tello et al. 2014), Brazil (Veiga \& Oliveira 1995, Sodré et al. 2004, Geiger \& Pacheco 2006, Nascimento et al. 2018), Venezuela (Soriano et al. 1993, Muñoz-Romo et al. 2014), and Argentina (Romano et al. 2015). In frugivorous phyllostomids, these cases have been reported in Venezuela (Muñoz-Romo et al. 2014, Melo-Torres \& Salazar-Candelle 2016), Colombia (Roncancio \& Ramírez-Chaves et al. 2008, Marín-Vasquez et al. 2010, Velandia-Perilla et al. 2013, Olarte-González et al. 2014, Chacón et al. 2015, Calderón-Álvarez \& Marín-Vásquez 2018), Peru (Medina \& López 2008, Ruelas et al. 2016), Argentina (Barquez et al. 2003), and Brazil (Oliveira \& Aguiar 2008, Souza et al. 2013, Rocha et al. 2013, Falcão 2014, Rosa et al. 2017) in various species in the genera Sturnira, Artibeus, and Carollia.

In Ecuador, three cases of atypical colorations have been recorded in bats, all belonging to the Phyllostomidae family: leucism in Carollia perspicillata (Boada \& Tirira 2010) and Artibeus fraterculus (Fernández de Córdova et al. 2017) and albinism in Vampyrum spectrum (Brito \& León 2014). Here, we report new cases of leucism in Molossus molossus Pallas, 1766 and Stunira bakeri Velazco and Patterson, 2014 from the lowland of western Ecuador; these are the first documented cases of leucism in these bat species in Ecuador.

\section{Materials and methods}

The leucism cases were recorded in three localities from lowland of western Ecuador:

1) Bosque Protector Cerro Blanco ( $\left.2^{\circ} 10^{\prime} \mathrm{S} ; 80^{\circ} 0^{\prime} \mathrm{W}\right)$. This is a private reserve, managed by Fundación ProBosque, and it is located at the southernmost end of the Chongón-Colonche Range on the edge of the urban area of the city of Guayaquil, in the province of Guayas. The predominant vegetation is secondary dry forest, with disturbed areas and small mature patches. Sampling was conducted near an artificial refuge, which is close to the main road and residential areas and a less than one kilometer from a mining area. The refuge is an abandoned house built of cement block walls and pillars and roofed with palm leaves, locally known as "cade". The bats were captured during the rainy season in February 2016.
2) Cerro Cacharí $\left(1^{\circ} 46^{\prime} \mathrm{S}, 7^{\circ} 27^{\prime} \mathrm{W}\right)$. This is private land located eight kilometers from the city of Babahoyo in the province of Los Ríos. This is a forested remnant located in a transition zone between deciduous (dry) forests and evergreen (humid) forests. Cacharí is formed by a small rocky outcrop with fractured plutonic rocks, including a main cave and numerous cracks. The structure forms a small hill in the midst of a floodplain, and there are large areas of rice crops around it. Non-systematic samplings were carried out from December 2016 to June 2018, both in the cave and around the rest of the forest remnant.

3) Isla Santay National Recreation Area ( $2^{\circ} 13^{\prime} S$; $79^{\circ} 52^{\prime} \mathrm{W}$ ). This protected area is managed by the Ministerio de Ambiente y Agua de Ecuador. It comprises a wetland located in the Guayas River and has flooded areas, shrub, and dry forest remnants towards the center; it is surrounded by mangroves. Isla Santay is between two large cities, Guayaquil y Eloy Alfaro (Durán), in the province of Guayas. The island contains a small community, called "Ecoaldea"; the M. molossus individuals were captured in the houses of this community. The sampling was carried out in November of 2019.

Bats were caught using mist nets. External morphometric measurements (in $\mathrm{mm}$ ) were taken using a digital caliper as follows: forearm length (FA), tail length (T), head-body length (HB), foot length (F), and ear length (E). The age class (juvenile, subadult, or adult) was determined by observing the epiphyseal-diaphyseal fusion (Brunet-Rossinni \& Wilkinson 2009); the reproductive condition was determined by direct observation of primary sexual characteristics (Racey 2009). We followed the guidelines of the American Society of Mammalogists (Sikes et al. 2016) for animal handling.

The molossids were identified as Molossus molossus based on the following morphological and morphometric characteristics: smooth upper lip without grooves, small, rounded ears rising from the same point on the forehead, antitragus taller than wide, bicolored fur, and forearm length (FA) between $35-40 \mathrm{~mm}$. These characteristics distinguish $M$. molossus from other species in the same genus that also inhabit western Ecuador, such as $M$. bondae, which has fur of a single color, and M. rufus, which has a FA greater than $50 \mathrm{~mm}$ (Eger 2008; Díaz et al. 2016; Tirira 2017). The populations of M. molossus that dwell in the western Andes in Ecuador are recognized as M. m. daulensis (Brosset 1965; Eger 2008). Before release, each individual was photographed, except for MZUGM-605.

The specimen of Sturnira was identified as S. bakeri due to the following characteristics: tetracolored dorsal hair, observable in stereo microscope, short and woolly fur approximately $5 \mathrm{~mm}$ in length between the shoulders, tricolor ventral hair, sparsely hairy forearm, dorsal surface of the femur, tibia, and foot densely covered by long hairs, IV metacarpal shorter than III metacarpal, and somatic measurements (FA, T, HB, F, E) in accordan- 
ce with those described for the species. Cranio-dental diagnostic features observed were oval sphenorbital fissure, globular cranial box, narrow face, well-developed sagittal crest, absent anterior process of the glenoid fossa, and metaconid and entoconid in well-defined M1 and M2, separated from each other by a deep notch (Velazco \& Patterson 2014; Sánchez \& Pacheco 2016; MontoyaBustamante et al. 2017). The collected specimens were deposited in the mammal collection of the Museo de Zoología of the Universidad de Guayaquil (MZUGM).

\section{Results}

The caught leucistic individuals of Molossus molossus were six individuals $(q=5 ; \hat{0}=1)$ from Cerro Blanco, one sub-adult female (MZUGM-605) from Cerro Cacharí inside the cave, and ten individuals $(q=8, \widehat{\delta}=2)$ from Isla Santay. Table 1 shows external measurements, age, and reproductive conditions of these individuals. The specimens of $M$. molossus presented white spots or patches on the head, ears, legs, throat, propatagium, and uropatagium; bats from Isla Santay also presented dorsal and ventral fur with silverish tips.

The specimen of Sturnira bakeri was a pregnant female (MZUGM-705; FA= 44; $\mathrm{HB}=64.3 ; \mathrm{F}=17.7 ; \mathrm{E}=15.8$; Weight: $31 \mathrm{~g}$ ), captured with mist-nets in the forest remnant of Cerro Cacharí; the individual presented a whitish-yellowish patch on its dorsal region, from the top of the upper left scapular region to the apophysis of the scapula, in contrast to the coloration normally present in yellow-shouldered bats. Figure 1 shows the individuals with leucism of both species.

\section{Discussion}

Bats with chromatic disorders have not been reported before in reserves from western Ecuador (Carrera et al. 2010, Fernández de Córdova et al. 2017, Parker \& Carr 1992, Salas 2008). Our leucistic individuals from Guayas represent the first cases for this geographical region, and were not apparently related to external morphology, age or reproductive condition (Eger 2008; Velazco \& Patterson 2014; Díaz et al. 2016; Tirira 2017; García-Morales et al. 2012, 2013; Sánchez-Hernández et al. 2010).

The chromatic abnormalities found in M. molossus were observed in different body regions (ears, tragus, throat, chest, abdomen, back, wings, legs, propatagium, uropatagium), and constitute the first known cases of leucism for this species. Previously, only albinism cases had been reported in $M$. molossus (Nascimiento et al. 2018, Soriano et al. 1993, Veiga \& Oliveira 1995, Tello et al. 2014). The appearance of this condition in various individuals during a single sampling, near their known refuge was remarkable (Lucati \& López-Baucells 2016, Uieda 2000, Zalapa et al. 2016), so it is likely they belonged to the same colony.

Table 1. External morphometric measurements (in $\mathrm{mm}$ ) of leucistic Molossus molossus individuals: forearm length (FA), tail length $(T)$, head-body length $(H B)$, leg length $(L)$ and ear length (E). KMR corresponds to the field acronym of Karina Marcillo-Rodríguez, MZUGM corresponds to the code of the mammal collection in Museo de Zoología of Universidad de Guayaquil, and IS is the field code that corresponds to Isla Santay.

\begin{tabular}{|c|c|c|c|c|c|c|c|c|}
\hline $\mathbf{N}^{\circ}$ & CODE & SEX & FA & $\mathbf{T}$ & HB & $\mathbf{L}$ & E & Age, reproductive condition \\
\hline 1 & KMR 01 & q & 37 & 18 & 52 & 17 & 10 & Adult, pregnant \\
\hline 2 & KMR 06 & q & 36 & 19 & 50 & 11 & 11 & Subadult, inactive \\
\hline 3 & KMR 07 & q & 36 & 33 & 46 & 12 & 8 & Subadult, inactive \\
\hline 4 & KMR 09 & q & 35 & 22 & 51 & 11 & 11 & Subadult, inactive \\
\hline 5 & KMR 10 & q & 34 & 25 & 54 & 14 & 9 & Adult, Pregnant \\
\hline 6 & KMR 13 & $\hat{\sigma}$ & 36 & 24 & 44 & 13 & 9 & Adult, inactive \\
\hline 7 & MZUGM-605 & ㅇ & 34 & 30 & 52 & 15 & 10 & Subadult, inactive \\
\hline 8 & IS-27 & q & 36 & 32 & 50 & 15 & 7 & Adult, inactive \\
\hline 9 & IS-28* & $\hat{0}$ & 37 & 36 & 50 & 22 & 7.5 & Juvenile, inactive \\
\hline 10 & IS-29 & 우 & 36 & 33 & 54 & 18 & 9 & Adult, inactive \\
\hline 11 & IS-31** & q & 36 & 35 & 55 & 21 & 9 & Juvenile, inactive \\
\hline 12 & IS-34* & q & 36.5 & 37 & 47 & 19.5 & 8 & Juvenile, inactive \\
\hline 13 & IS-35 & q & 35 & 31 & 39 & - & 10 & Juvenile, inactive \\
\hline 14 & IS-36* & q & 37 & 37 & 48 & 19 & 9 & Adult, inactive \\
\hline 15 & IS-40 & q & 37 & 32 & 54 & 19 & 10 & Adult, inactive \\
\hline 16 & IS-41 & $\hat{o}$ & 36.5 & 34 & 49 & 22 & 11 & Adult, scrotal testes \\
\hline 17 & IS- $42 * * *$ & q & 35 & 36 & 50 & 19 & 10.3 & Juvenile, inactive \\
\hline
\end{tabular}



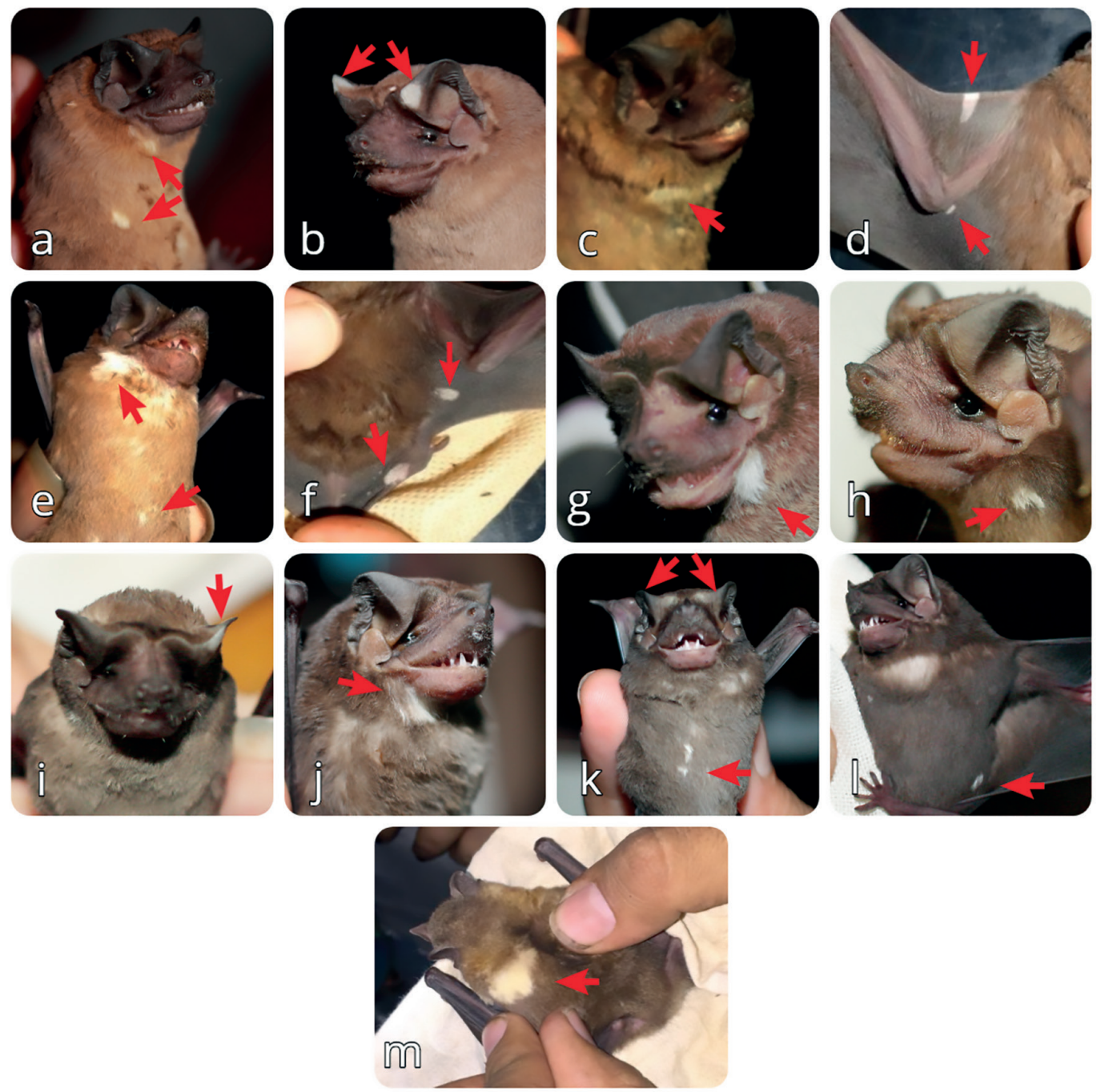

Figure 1. Leucistic bats: red arrows indicate pigmentary disorders. KMR corresponds to the field acronym of Karina Marcillo-Rodríguez for the individuals captured in Cerro Blanco, MZUGM corresponds to the code of mammal collection in the Museo de Zoología of Universidad de Guayaquil for individuals collected in Cerro Cacharí, and IS is the field code that corresponds to Isla Santay. Molossus molossus: a) KMR-01: pregnant female with various white spots on abdomen, b) KMR-06: subadult female with white spots on inner edge of ears, c) KMR-07: subadult female with whitish patch in pectoral region, d) KMR-09: subadult female with whitish spots on propatagium and left wing, e) KMR-10: pregnant female with extensive white patch on chest and various white spots on abdomen, f) KMR-13: male with white spots on right wing and uropatagium, g) MZUGM-605: subadult female with white spot on neck, h) IS-27: adult female with white spot on neck, i) IS-29: adult male with white spot on neck and inner edge of left ear, j) IS-35: adult female with white spot on neck and diffuse dorsal and ventral spots, k) IS-40: adult female with white spot on right leg, two small white spots on chest, and silverish discoloration on basal part of tragus and ears I) IS-41: female presents silver-tipped abdominal fur and white spot on left ventral side. Sturnira bakeri: m) MZUGM-705: pregnant female with whitish-yellowish patch on dorsal region, from the beginning of upper left scapular region to apophysis of scapula. All photos taken by Jaime Salas except for $c, d, e$, and f, which were taken by Lissette Torres.

In contrast to the leucistic M. molossus individuals, the Sturnira bakeri specimen was not captured near its refuge, but rather on its flight path through the forest, which is infrequently recorded for bats (Rose et al., 2017). Our report of leucism in $S$. bakeri is the first for the species, since previous cases have been recorded in different species of Sturnira such as $S$. hondurensis (García-Morales et al. 2012), S. erytrhomos (Barquez et al. 2003; Roncancio \& Ramírez-Chaves 2008), S. parvidens (Zalapa et al. 2016), and S. lilium (Medina \& López 2008; Melo-Torres
\& Salazar-Candelle 2016), in pregnant females, males, and subadults of these species.

Although chromatic aberrations in bats seem to be a worldwide phenomenon, South America has a significant information gap (Lucati \& López-Baucells 2016), and the little known comes from last few years (Hernández-Aguilar \& Santos-Moreno 2018, Rose et al. 2017, Ruelas et al. 2016, Tello et al. 2014, Zortéa \& Silva 2018). Therefore, these chromatic disorders and their causes should be investigated in order to complement available data on the subject. 


\section{Literature cited}

Barquez RM, Carrizo LV, Ferro LI, Flores DA, Mollerach ML, Sánchez MS, García-López AP. 2003. Primer caso de albinismo total para Sturnira erythromos (Tschudi, 1844) (Chiroptera-Phyllotomidae). Chiroptera Neotropical 9 (1-2): 166-169.

Bensch S, Hansson B, Hasselquist D, Nielsen B. 2000. Partial albinism in a semi-isolated population of great reed warblers. Hereditas 133: 167-170. https://doi. org/10.1111/j.1601-5223.2000.t01-1-00167.x

Boada C, Tirira D. 2010. First record of partial albinism (leucism) in Carollia perspicillata (Phyllostomidae) in Ecuador. Chiroptera Neotropical 16 (2): 755-757.

Brito J, León C. 2014. Primer caso de albinismo en Vampyrum spectrum (Chiroptera: Phyllostomidae) para Ecuador. Mammalogy Notes 1: 14-15. https://doi. org/10.47603/manovol1n2.14-15

Brosset A. 1965. Contribution al'etude des chiropteres de l'oest de l'Ecuador. Mammalia 29: 211-227. https://doi. org/10.1515/mamm.1965.29.2.211

Brunet-Rossinni AK, Wilkinson GS. 2009. Methods for Age Estimation and the study of senescence in bats. In: T.H. Kunz \& S. Parsons, eds. Ecological and behavioral methods for the study of bats. Johns Hopkins University Press. Maryland, USA. Pp. 315-323.

Caire W, Thies M. 1988. Notes on the occurrence of morphological and color aberrations in bats from Oklahoma, Missouri, and Mexico. Proceedings of the Oklahoma Academy of Science 68: 75-76.

Calderón-Álvarez A, Marín-Vásquez A. 2018. Rare colour aberration in the short-tailed fruit bat (Carollia perspicillata). Biodiversity International Journal 2(1): 64-65. https://doi.org/10.15406/bij.2018.02.00045

Carrera JP, Solari S, Larsen PA, Alvarado DF, Brown AD, Carrión C, Tello JS, Baker RJ. 2010. Bats of the Tropical Lowlands of Western Ecuador. Special Publications, Museum of Texas Tech University 57: 1-37. https:// doi.org/10.5962/bhl.title.142936

Chacón PJJ, González-Charrasquiel CM, Ballesteros-Correa J. 2015. Records of leucism in Artibeus planirostris (Chiroptera: Phyllostomidae) in Colombia. Acta Zoológica Mexicana 31(1): 125-128. https://doi.org/10.21829/ azm.2015.311526

Chętnicki W, Fedyk S, Bajkowska U. 2007. Cases of coat colour anomalies in the common shrew, Sorex araneus L. Folia Biologica (Krakow) 55: 73-76. https://doi. org/10.3409/173491607780006308

Díaz MM, Solari S, Aguirre LF, Aguiar LMS, Bárquez RM. 2016. Clave de identificación de los murciélagos de Sudamérica. Publicación Especial Nº2. Programa de Conservación de los Murciélagos de Argentina-PCMA. 160 pp.

Eger J. 2008. Familiy Molossidae P. Gervais, 1856. In: A.L. Gardner, ed. Mammals of South America, Volume 1: Marsupials, Xenarthrans, Shrews, and Bats. The University of Chicago Press. Chicago, USA. Pp: 399-440.

Falcão FC. 2014. First record of complete albinism in Carollia perspicillata (Chiroptera; Phyllostomidae). Chiroptera Neotropical 20(1): 1234-1236.

Fernández de Córdova CJ, Nivelo-Villavicencio CH, Webster PXA. 2017. Primer reporte de leucismo para Artibeus fraterculus (Chiroptera: Phyllostomidae) en Ecuador. Revista Biodiversidad Neotropical 7(2): 114-118. https://doi.org/10.18636/bioneotropical.v7i1.555
García-Morales R, Tejera DD, Ávila GES, Moreno CE, Akmentis MS. 2012. Registro de leucismo en Sturnira ludovici y Artibeus jamaicensis (Phyllostomidae) en México. Chiroptera Neotropical 18 (1): 1101-1105.

García-Morales R, Rojas-Martínez AE, Ávila-Gómez ES, Moreno CE. 2013. Leucism in the giant fruit-eating bat (Artibeus lituratus Olfers, 1818) in the state of Hidalgo, Mexico. Chiroptera Neotropical 19 (2): 1212-1215.

Geiger D, Pacheco SM. 2006. Registro de albinismo parcial em Nyctinomops laticaudatus (E. Geoffroy, 1805) (Chiroptera: Molossidae) no Sul do Brasil. Chiroptera Neotropical 12(1): 250-254.

Hernández-Aguilar I, Santos-Moreno A. 2018. First records of hypopigmentation disorders in the Peter' ghostfaced bat Mormoops megalophylla (Chiroptera, Mormoopidae). Mammalia 82(6): 618-621. https://doi. org/10.1515/mammalia-2017-0075

Hernández-Mijangos LA. 2009. Registros de albinismo parcial en tres especies de murciélagos filostómidos (Chiroptera: Phyllostomidae) en Chiapas, México. Chiroptera Neotropical 15(1): 441-445

Holyoak DT. 1978. Variable albinism of the flight feathers as an adaptation of recognition of individual birds in some Polynesian populations of Acrocephalus warblers. Ardea 66: 112-117.

Idoeta F, De Santis LJM, Bárquez RM. 2011. Leucismo en Eptesicus furinalis (d'Orbigny y Gervais, 1847) (Chiroptera: Vespertilionidae) en la provincia de Corrientes, Argentina. Chiroptera Neotropical 17(2): 985-988.

Lucati F, López-Baucells A. 2016. Chromatic disorders in bats: A review of pigmentation anomalies and the misuse of terms to describe them. Mammal Review 47(2): 112123. https://doi.org/10.1111/mam.12083

Marín-Vasquez A, Ortega-Rincón M, Ramírez-Chaves HE. 2010. Records of leucism in three species of Colombian bats: Carollia brevicauda, Artibeus jamaicensis and Lophostoma silvicolum. Chiroptera Neotropical 16(2): 706-709

Medina C, López E. 2008. Primer registro de leucismo en Sturnira lilium en el Sureste del Perú. Chiroptera Neotropical 16(2): 758- 761

Melo-Torres GC, Salazar-Candelle M. 2016. Primer registro para Venezuela de leucismo en Sturnira lilium (Chiroptera: Phyllostomidae). Acta Biológica Venezolana 36(1): 33-43.

Moller AP, Mousseau TA. 2001. Albinism and phenotype of Barn Swallows (Hirundo rustica) from Chernobyl. Evolution 55(10): 2097-2104. https://doi. org/10.1111/j.0014-3820.2001.tb01324.x

Montoya-Bustamante, S., B. González-Chávez, N. Zapata-Mesa \& L. Obando-Cabrera. 2017. First records of Sturnira bakeri Velazco \& Patterson, 2014(Chiroptera: Phyllostomidae) from Colombia. Check List 13(2): 2091. https://doi.org/10.15560/13.2.2091

Muñoz-Romo M, Ruiz-Ramoni D, Ramoni-Perazzi P. 2014. First record of leucism in the giant fuit-eating bat Artibeus amplus (Chiroptera: Phyllostomidae). Chiroptera Neotropical 20(2): 1301-1304

Nascimento ACS, Dourado ACM, Trevelin LC, Bezerra MZ. 2018. First record of total albinism in Molossus molossus (Chiroptera: Molossidae) from Northeastern Brazil. Boletim do Museu Paraense Emílio Goeldi. Ciências Naturais 13(2):273-277. 
Olarte-González G, Vela-Vargas LM, Camargo P, Jhonson T, Jiménez A. 2014. Primer reporte de leucismo en Artibeus lituratus (Olfers, 1818) (Phyllostomidae: Stenodermatinae) en el Caribe colombiano. Mammalogy notes 1(1): 7-8. https://doi.org/10.47603/manovol1n1.7-8

Oliveira HFM, Aguiar LMS. 2008. A new case of complete albinism in a bat from Brazil. Chiroptera Neotropical 14(2): 421-423

Parker III TA, Carr JL. 1992. Status of forest remnants in the Cordillera de la Costa and adjacent of Southwester Ecuador. Conservation International. Rap Working Papers 2. $171 \mathrm{pp}$.

Racey PA. 2009. Reproductive Assessment of bats. In: T.H. Kunz \& S. Parsons, eds. Methods of capturing and handling bats. Ecological and behavioral methods for the study of bats. Johns Hopkins University Press. Maryland, USA. Pp: 249-264.

Rocha PA, Feijó JA, Ramos-Donato C, Ferrari SF. 2013. Leucism in Seba's short-tailed bat Carollia perspicillata (Linnaeus, 1758) from a rock shelter in northeastern Brazil. Chiroptera Neotropical 19(1): 1151-1153.

Romano MC, Montani ME, Cordini MC, Auil S. 2015. First record of albinism in Tadarida brasiliensis (Chiroptera: Molossidae) in South America and new records of leucism in central Argentina. Chiroptera Neotropical 21: 1312-1329.

Roncancio N, Ramírez-Chaves HE. 2008. Registro de leucismo en Sturnira erythromos en los Andes centrales de Colombia. Chiroptera Neotropical 14(2): 412-414.

Rose AR, Martorelli LFA, de Almeida MF, Aires CC. 2017. Albinism in Carollia perspicillata (Chiroptera; Phyllostomidae), in the state of Rondônia, Brazil. A brief review of albinism in bats. Biotemas 30(3): 71-77. https:// doi.org/10.5007/2175-7925.2017v30n3p71

Ruelas D, Ramos M, Molina M, Pacheco V. 2016. Primer registro de leucismo en Glossophaga soricina valens (Phyllostomidae: Chiroptera) en Perú. Therya 7(2): 343-352. https://doi.org/10.12933/therya-16-381

Salas J. 2008. Murciélagos del Bosque Protector Cerro Blanco. Chiroptera Neotropical 14(2): 397-402.

Sánchez P, Pacheco V. 2016. New record of Sturnira bakeri Velazco \& Patterson, 2014 (Chiroptera: Phyllostomidae) from Northwestern Peru. Check List 12(5):1984. https://doi.org/10.15560/12.5.1984

Sánchez-Hernández C, Romero-Almaraz ML, Taboada-Salgado A, Almazán-Catalán A, Schnell GD, Sánchez-Vázquez L. 2010. Five albino bats from Guerrero and Colima, Mexico. Chiroptera Neotropical 16(1): 522-527.

Sikes RS and The Animal Care and Use Committee of The American Society of Mammalogists. 2016. 2016 Guidelines of the American Society of Mammalogists for the use of wild mammals in research and education. Journal of Mammalogy 97(3):663-688. https://doi. org/10.1093/imammal/gyw078

Sodré MM, Uieda W, Baldim M. 2004. First record of Albinism in the bat Eumops glaucinus (Molossidae) from Southeastern Brazil. Chiroptera Neotropical 10 (1-2): 200-201.

Soriano PJ, Utrera A, Sosa M. 1993. Dos registros de murciélagos albinos para Venezuela. Biollania 9: 149-150.

Souza RF, Novaes RLM, Felix S, Sauwen C, Jacob G, Santori RT, Avilla LS. 2013. First record of leucism in Artibeus lituratus (Olfers, 1818) (Phyllostomidae) in Brazil. Chiroptera Neotropical 19(2): 1216-1219.
Tello C, Streicker DG, Gómez J, Velazco PM. 2014. New records of pigmentation disorders in molossid and phyllostomid (Chiroptera) bats from Peru. Mammalia 78(2): 191197. https://doi.org/10.1515/mammalia-2013-0019

Tirira DG. 2017. Guía de campo de los Mamíferos del Ecuador. Editorial Murciélago Blanco. Publicación Especial de los Mamíferos del Ecuador 11. Quito. Pp 600.

Uieda W. 2000. A review of complete albinism in bats with five new cases from Brazil. Acta Chiropterologica 2(1): 97105.

Velandia-Perilla JH, Yusti-Muñoz AP, Sánchez-Martínez MA, Giraldo A. 2013. Leucismo en murciélagos de hoja nasal (Chiroptera, Phyllostomidae) de Colombia. Boletín Científico del Centro de Museos 17(2): 87-94.

Velazco PM, Patterson BD. 2014. Two new species of yellow shouldered bats, genus Sturnira Gray, 1842 (Chiroptera, Phyllostomidae) from Costa Rica, Panama and western Ecuador. Zookeys 402: 43-66. https://doi. org/10.3897/zookeys.402.7228

Veiga LA, Oliveira ATD. 1995. A case of true albinism in the bat Molossus molossus Pallas (Chiroptera, Molossidae) in Santa Vitoria do Palmar, RS, Brazil. Arquivos de Biologia e Tecnologia 38: 879 - 881.

Zalapa S., Guerrero S, Romero-Almaraz M, Sánchez-Hernández C. 2016. Coloración atípica en murciélagos: frecuencia y fenotipos en Norte y Centroamérica e islas del Caribe y nuevos casos para México y Costa Rica. Revista Mexicana de Biodiversidad 87(2): 474-482. https:// doi.org/10.1016/j.rmb.2016.04.007

Zortéa M, Silva MC. 2018. Albinism in the striped spearnosed bat Gardnerycteris crenulatum (Chiroptera: Phyllostomidae) with an updated list of albino bats in the World. Mammalia 82(1):78-84. https://doi. org/10.1515/mammalia-2016-0080

\begin{abstract}
Agradecimientos / Acknowledgments:
We thank P. Cun (Fundación ProBosque / Bosque Protector Cerro Blanco), A. Morán, A. Torres, B. Domínguez, M.F. Cruz, and A. Briones (Ministerio de Ambiente de Ecuador / Recreation National Area Isla Santay) for logistics and support. Also, we thank J. Anzules, T. Paz, A. Au Hing, R. Bravo, for their assistance in the fieldwork. Special thanks to S. Mejillón-LaMontage and J. Collins for the English assistance. Thanks to V. Romero and B. Pernía for their helpful comments.
\end{abstract}

Conflicto de intereses / Competing interests:

The authors declare no have been conflict of interest.

Rol de los autores / Authors Roles:

JAS: conceptualization, research, curation of specimens, wrote the initial manuscript field work analysis of data. LT: writing proofreading and editing, field work. analysis of data. KM: writing, revision and editing, field work. analysis of data. MM: specimen curation, writing, proofreading and editing, field work, data analysis.

\section{Fuentes de financiamiento / Funding:}

This research received no specific grant from any funding agency, commercial or not-for-profit sectors.

\section{Aspectos éticos / legales; Ethics / legals:}

The capture and collection of bats were made with the research permits 04-2016-IC-FLO / FAU-DPG / MAE (province of Guayas), and N ${ }^{\circ}$ MAE-DPALR-2017-0234-O (province of Los Ríos) provided by Ministerio de Ambiente de Ecuador, for the Project of Universidad de Guayaquil: Estudios Prioritarios para la Conservación de Mastofauna en la costa de Ecuador Parte 1: Piso Suroccidental (FCl 031- 2017). 